Provided for non-commercial research and education use. Not for reproduction, distribution or commercial use.

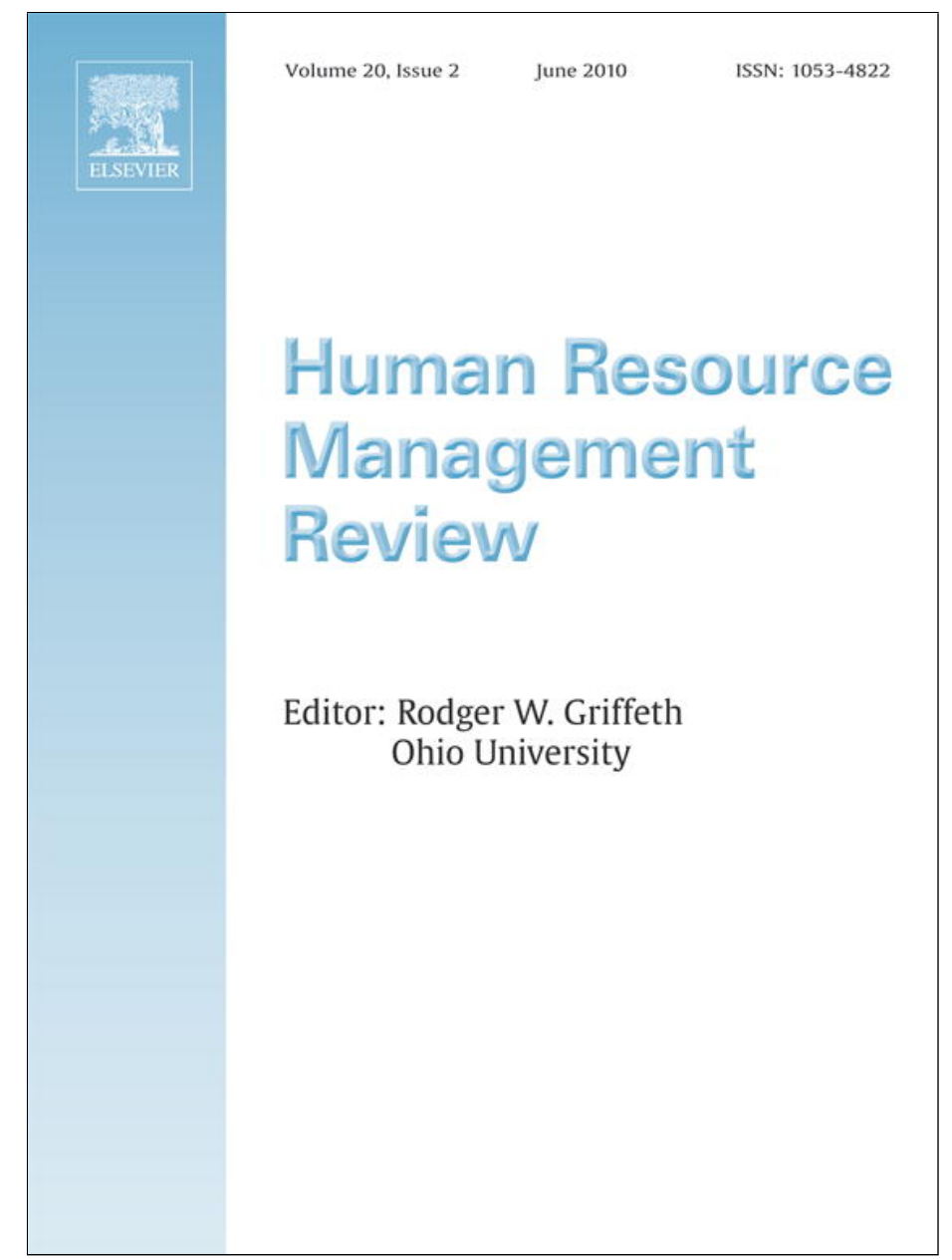

This article appeared in a journal published by Elsevier. The attached copy is furnished to the author for internal non-commercial research and education use, including for instruction at the authors institution and sharing with colleagues.

Other uses, including reproduction and distribution, or selling or licensing copies, or posting to personal, institutional or third party websites are prohibited.

In most cases authors are permitted to post their version of the article (e.g. in Word or Tex form) to their personal website or institutional repository. Authors requiring further information regarding Elsevier's archiving and manuscript policies are encouraged to visit:

http://www.elsevier.com/copyright 


\title{
Work-life balance policy and practice: Understanding line manager attitudes and behaviors
}

\author{
Alma McCarthy ${ }^{\mathrm{a}, *}$, Colette Darcy ${ }^{\mathrm{b}, 1}$, Geraldine Grady ${ }^{\mathrm{c}, 2}$ \\ a Department of Management, J.E. Cairnes Graduate School of Business E Public Policy, National University of Ireland, Galway, Galway, Ireland \\ b School of Business, National College of Ireland, Mayor Street - IFSC, Dublin 1, Ireland \\ c Centre for Innovation and Structural Change, National University of Ireland, Galway, Galway, Ireland
}

A R T I C L E I N F O

\section{Introduction}

Work-life balance (WLB) is an important area of human resource management which is receiving increasing attention from policy makers, organizations, management, employees and their representatives globally. In the US, recent studies highlight the phenomenon of "extreme jobs" characterized by grueling working hours, unpredictable workflows, fast work pace with tight deadlines, work-related events outside business hours, and 24/7 availability to clients (Hewlett \& Luce, 2006; Hochschild, 1997). In Europe, a recent study conducted by The Boston Consulting Group and the EAPM (2007) of HR Directors across Europe, work-life balance is ranked as one of the top three challenges facing HR. In the UK, Worrall, Jones, and Cooper (2003: 3) reflect on the findings of the Quality of Working Life project and argue that "the evidence we have obtained ... leads us to conclude that the increased employment instability, the intensification and extensification of work that has taken place over the last ten years is unsustainable in terms of its impact on the working and non-working lives of UK managers". If Worrall et al.'s (2003) prediction of the deleterious impact of recent workplace changes on managers is borne out, then the effect of such changes on employee WLB should be investigated.

Work-life balance is the general term used to describe organizational initiatives aimed at enhancing employee experience of work and non-work domains. Cascio (2000: 166) defines work-life balance programs as "any employer sponsored benefits or working conditions that help employees balance work and non-work demands". Work-life balance arrangements and practices refer to initiatives voluntarily introduced by firms which facilitate the reconciliation of employees' work and personal lives. Such initiatives include: temporal arrangements that allow employees to reduce the number of hours they work (e.g. job sharing where two employees share one job, part-time working where an employee works less than a full-time equivalent); flexible working arrangements such as flexi-time where employees choose a start and finish time which matches their personal needs but work

\footnotetext{
* Corresponding author. Tel.: + 35391492846.

E-mail addresses: alma.mccarthy@nuigalway.ie (A. McCarthy), cdarcy@ncirl.ie (C. Darcy), geraldine.grady@nuigalway.ie (G. Grady).

1 Tel.: + 35314498626 .

2 Tel.: + 35391495679
}

1053-4822/\$ - see front matter @ 2009 Elsevier Inc. All rights reserved. doi:10.1016/j.hrmr.2009.12.001

(c) 2009 Elsevier Inc. All rights reserved. 
certain core hours, tele-working/home-working/e-working where employees have locational flexibility in completing their work; work-life balance supports such as employee counselling, employee assistance programs, time management training, stress management training; and childcare facilities on-site or financial support for childcare off-site (e.g. through subsidised childcare). Essentially, work-life balance initiatives are offered by organizations to assist staff manage the demands of work and personal life (Grady, McCarthy, Darcy, \& Kirrane, 2008; McCarthy, 2004).

Work-life balance is a factor which has the potential to affect important workplace issues such as employee turnover, stress, job satisfaction, and productivity (Bloom \& Van Reenen, 2006; Frone, Russell, \& Cooper, 1992; Parasuraman, Purohit, Godshaulk, \& Beutell, 1996; Parris, Vickers, \& Wilkes, 2008; Thomas \& Ganster, 1995; Veiga, Baldridge, \& Eddleston, 2004). The implications of sometimes conflicting work and personal life responsibilities for people management and work structures are wide ranging (Fisher, 2000). De Cieri, Holmes, Abbott, and Pettit (2005) argue that the current highly competitive labor market, where the attraction and retention of highly valued employees is difficult, calls for greater awareness of employee work-life balance concerns. As a result, many organizations are exploring how they can help employees achieve more balance by offering a range of family or work-life balance policies and programs.

To-date, much of the research in the work-life balance arena has investigated individual level work-life balance factors such as employee demands for flexible working practices (Brannen \& Lewis, 2000; Coughlan, 2000; Den Dulk, 2001), employee satisfaction with work-life or work-family policies and programs (Anderson, Coffey, \& Byerly, 2002; Galinsky, Bond, \& Friedman, 1996), and impact of work-life balance programs on a number of employee level outcomes such as stress, commitment and productivity (Bedeian, Burke, \& Moffet, 1988; Darcy \& McCarthy, 2007; Grady \& McCarthy, 2008; Frone et al., 1992; Lambert, 2000; McCarthy \& Cleveland, 2005). Other research has explored how work-life balance affects performance at the organizational level (Bloom, Kretschmer, \& Van Reenen, 2006).

It is widely acknowledged in the WLB literature that line manager support for work-life balance is an important factor affecting employee WLB outcomes (Lapierre et al., 2008; Thomas \& Ganster, 1995; Thompson, Jahn, Kopelman, \& Prottas, 2004). Generally, employees whose line managers are more supportive of their WLB needs tend to be more satisfied with their jobs, experience less work-personal life conflict, and report lower turnover intentions. Notwithstanding the importance of line managers in WLB management, there remains a paucity of research, both theoretical and empirical, exploring how line managers enact and manage work-life balance policies and practices for their staff (Eby, Casper, Lockwood, Bordeaux, \& Brinley, 2005). Given that line managers play an increasingly active role in HRM decision-making, including work-life balance decisions (Bach, 1994; Hales, 2006; McConville \& Holden, 1999; Purcell \& Hutchinson, 2007; Storey, 1994), it is important to understand how line managers, who are a critical meso-level factor affecting organizational functioning in general (Hales, 2006), affect and influence work-life balance policy and practice. The definition of line managers for the current paper is that employed by Currie and Procter (2001) who note that line managers mediate, negotiate and interpret connections between the organization's institutional (strategic) and technical (operational) levels. Little is known about the factors affecting line manager support and how organizations can foster supportive WLB attitudes among line managers (Casper, Fox, Sitzmann, \& Londy, 2004; Eby et al., 2005). This paper aims to address this important gap in the theory by focusing on line managers in particular.

The purpose of this paper is to develop a conceptual model to explain what affects line manager WLB policy and practice behaviors and the consequent impact on employee WLB experience. This paper contributes to work-life balance theory and research in two important ways. First, the work-life balance literature is reviewed with particular reference to line management's role in work-life balance policy and practice management. Given the importance of line managers in enacting HR policies such as WLB, allied with the lack of focus to-date on the exact nature of line manager support for WLB, it is necessary to shed further light on this stakeholder group within the WLB field. Second, by using the theory of planned behavior (TPB), we develop a theoretically grounded model to identify and explain a set of factors which have the potential to affect line manager work-life balance behaviors. The model not only specifies the role of several variables in predicting line manager intentions to engage in specific behaviors but also can assist in understanding how work-life balance initiatives can lead to better outcomes for employees. The value of the TPB in understanding and predicting behavior in organizations is well recognized in the management literature (Hurtz \& Williams, 2009; Jimmieson, Peach, \& White, 2008; McCarthy \& Garavan, 2006). In terms of line managers and WLB in particular, the TPB provides a theoretical framework to identify the factors which affect line manager work-life balance management intentions and behaviors. By focusing on the line manager and applying the TPB to identify the predictors of WLB behaviors, this paper goes some way towards addressing the gap that remains in our understanding of work-life balance in organizations.

\section{HR and WLB policy and practice - the role of line managers}

Human resource management practice has seen a significant shift from centralized decision-making at senior management levels to decentralized devolved responsibility at line manager level (Bond \& Wise, 2003; Colling \& Ferner, 1992; Cunningham \& Hyman, 1999; Hales, 2006; Hall \& Torrington, 1998; Hutchinson \& Wood, 1995; Stoker, 2006). Line managers are playing more active roles in HR decision-making and the line manager acts as an intermediary between strategic and operational organizational activities (Dopson, Risk, \& Stewart, 1992; Hales, 2006; Stoker, 2006). The devolution of HR decision-making to line management inevitably means there is greater scope for disparity and inconsistencies between the policy formulated at senior HR level and the actual decisions taken by line managers. Legge (1995) argues that HR policy (rhetoric) can be somewhat divorced from actual practice (reality) and other research tends to support this view (Cunningham, James, \& Dibben, 2004; Purcell, Kinnie, Hutchinson, Rayton, \& Swart, 2003; Whittaker \& Marchington, 2003). As HR policies cascade down the organizational hierarchy, middle and line managers become relevant stakeholders in influencing how HR policies are interpreted and enacted. 
The impact of line managers on employee attitudes and performance is borne out by longitudinal research conducted by Purcell et al. (2003). They conducted a longitudinal study of twelve organizations in the UK exploring the link between human resource management practice and performance. A significant finding from the research is the role that front line managers or supervisors play in the actual implementation of HR policies and practices. They argue that "line managers have discretion in the way they practice good people management ..." (p. x).

Work-life balance policies are formally designed and adopted at the organizational level, usually by HR directors or managers. However, WLB policies are largely implemented and managed at the unit level by line managers and supervisors (McConville \& Holden, 1999; Parris et al., 2008; Purcell \& Hutchinson, 2007; Ryan \& Kossek, 2008). A critical link in the policy-practice dyad is the line manager or supervisor who enacts the human resource policy. The implementation and practice regarding these WLB policies can, therefore, operate quite differently across different organizational units/sections, managers, and locations depending on the line manager. It is, therefore, necessary to ensure that HR research adopts a multi-level and multi-perspective design to capture the different issues that arise at the policy and practice level to account for the potential effects of middle and line management WLB actions, attitudes and behaviors. A valuable multi-perspective contribution to the theory on work-life balance policy and practice is made by Kopelman, Ptottas, Thompson, and White Jahn (2006) who explored the impact of work-life balance program availability on positive attitudes and behaviors at the HR manager and employee levels. They investigated individual level and group level effects of work-life balance program availability and found that the more programs that were offered, the better a number of attitudinal outcome variables such as commitment and perceived organizational family support. Employees and HR managers were used in Kopelman et al.'s (2006) research design. However, the line manager/supervisor perspective was not explored. Poelmans and Sahibzada (2004) claim that there is a lack of research that has explored the actual implementation of work-family policies at the organization level. It seems timely and necessary, therefore, to explore the role line managers play in enacting work-life balance policy into practice given the argument that HR policy at senior levels in the firm can be different to the practice at line manager and employee levels.

As Hales (2006: 34) notes, line managers' duties are often "undertaken in circumstances of considerable ambiguity: being accountable for operational effectiveness but having limited authority or influence over the 'system' decisions that could determine effectiveness". Many work-life balance initiatives and programs adopted at a senior management level can inevitably mean a reduction in working time, for example, part-time working, term-time, and job sharing. These programs can create real challenges for line managers as they are trapped between conflicting demands of maintaining or increasing productivity and yet allowing for flexibility or decreased working time. Some evidence is available about the influence of line managers on certain work-life balance issues. For example, research reveals that the line manager plays an important role in work-family program participation (Casper et al., 2004; Thompson, Beauvais, \& Lyness, 1999; Warren \& Johnson, 1995; Wise, 2005). In other cases, the research finds high levels of variability among line managers in terms of their understanding of particular work-life polices leading to inconsistent application across different employees (Wise, 2005). Despite the growing recognition of the importance of supervisor and line managers in worklife balance, little research has explored factors that relate to supervisor support for and behaviors surrounding work-family balance programs. The following sections of the paper attempt to address this gap by using the theory of planned behavior to identify a set of factors to explain line manager WLB attitudes and behaviors and the consequent impact on employee WLB experience.

\section{The theory of planned behavior}

The theory of planned behavior is a dispositional approach to the prediction of behavior (Ajzen, 1991). Ajzen points out that the theory of planned behavior "is a theory designed to predict and explain human behavior in specific contexts" (p. 181). The specific context that is relevant in this paper is line manager WLB policy and practice attitudes and behaviors. According to the theory of planned behavior, a person's behavior is determined by his/her intention to perform the behavior and that this intention is, in turn, a function of his/her attitude towards the behavior and his/her subjective norms (see Fig. 1). The best predictor of behavior is intention (Ajzen, 1991). Intention is the cognitive representation of a person's readiness to perform a given behavior, and it is considered to be the immediate antecedent of behavior. This intention is determined by three things: attitude toward the specific behavior, subjective norms, and perceived behavioral control.

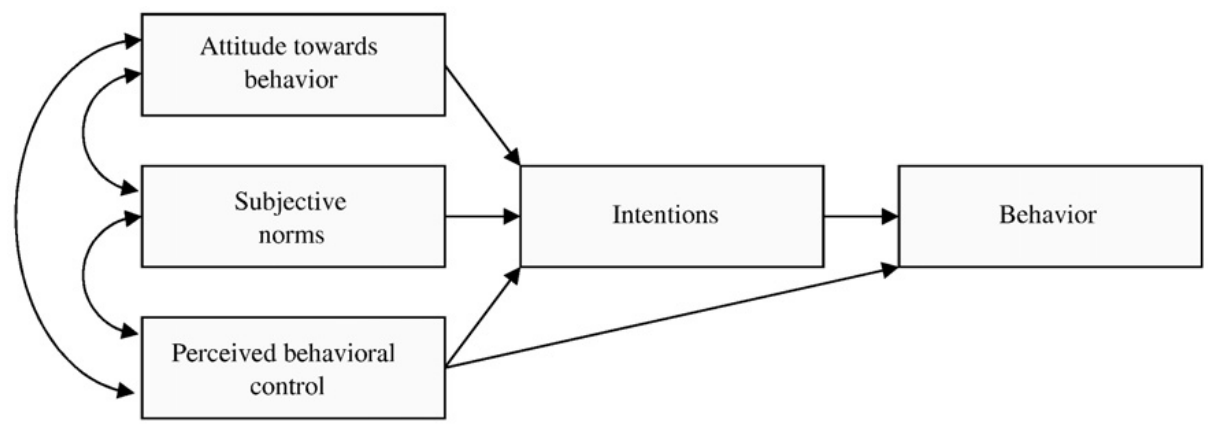

Source: Ajzen (1991)

Fig. 1. Theory of planned behavior. 
Attitudes, subjective norms and perceived behavioral control predictors lead to intentions to perform a given behavior. According to Ajzen (1991: 181), "intentions are assumed to capture the motivational factors that influence a behavior; they are indications of how hard people are willing to try ... in order to perform the task". In addition to measuring attitudes toward the behavior, we also need to measure subjective norms which refer to beliefs about how relevant others will view the behavior in question. Finally, perceived behavioral control influences intentions but can also directly affect behavior. Perceived behavioral control refers to perceptions of ability to perform a given behavior. Ajzen (1991) argues that perceived behavioral control also has the ability to directly affect behaviors since behavioral intention cannot be the exclusive determinant of behavior where an individual's control over the behavior is incomplete. In other words, the performance of behaviors depends on non-motivational factors such as availability of requisite opportunities and resources (e.g. financial, staffing etc.). According to the theory of planned behavior, perceived behavioral control, together with behavioral intention, can be used directly to predict behavioral achievement. As a general rule, the more favorable the attitude and the subjective norm, and the greater the perceived control, the stronger the person's intention to perform the behavior in question.

\section{Applying the theory of planned behavior to understand line manager work-life balance attitudes and behaviors}

In the context of line manager work-life policy and practice behaviors, the theory of planned behavior implies that line managers who have more positive attitudes towards work-life balance programs, who experience greater social pressure (subjective norms) to implement work-life balance policies and practices, and who perceive they have more control over WLB policy formation and implementation will have greater intentions to adopt and implement such programs compared to line managers with less favorable attitudes. What, then, are the particular factors which affect line manager WLB behavior intentions and subsequent WLB behaviors and actions? Fig. 2 presents a model of the TPB as applied to line manager WLB policy and practice attitudes and behaviors and each of these elements are discussed in turn below.

\subsection{Attitudes towards behavior}

\subsubsection{Line manager WLB Policy awareness}

The TPB postulates that attitudes towards given behaviors affect intentions to engage in a behavior and thus subsequent actual behavior. Applying the theory of planned behavior, an important factor determining attitudes towards WLB policies and practices would be line managers' awareness and knowledge of the existence of such policies and practices, as well as how to implement and manage them. The extent to which line managers are aware of the work-life balance policies and practices available in the organization is an important factor in determining their WLB management intentions and behaviors.

Research indicates that lack of awareness of various HR policies in general by line managers negatively impacts their effectiveness (Casper et al., 2004; Harris, Blair, \& Grandey, 2002). Bond and Wise (2003) report large scale inconsistency among managers regarding family leave policy provision within their organization thereby highlighting that line managers can use their discretion to engage differently in work-life balance management. They go on to report high levels of confusion over terminology

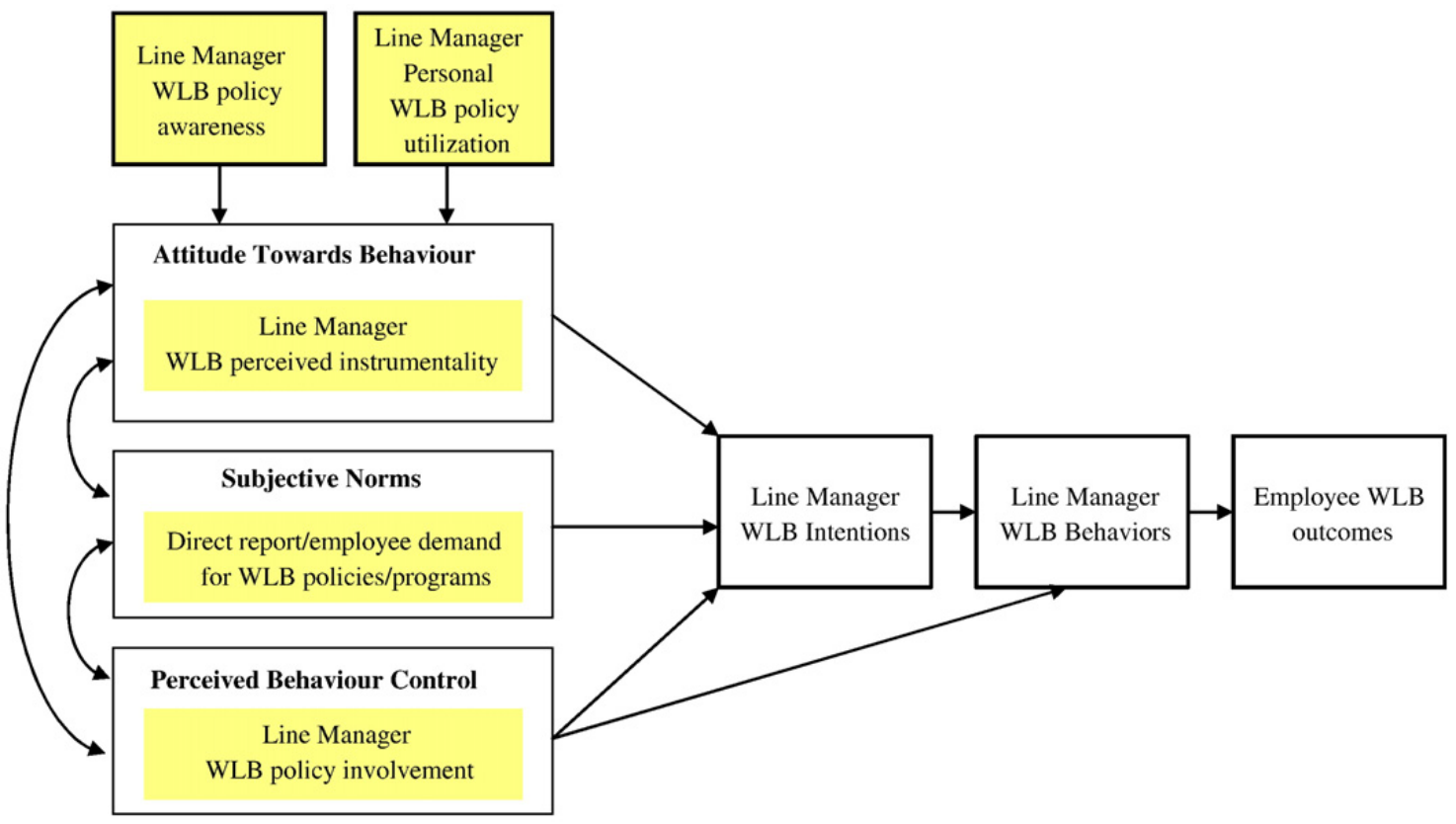

Fig. 2. Conceptual model of line manager WLB attitudes and behaviors. 
among line managers which had deleterious effects on ensuring consistent organizational-wide responses to work-life balance issues. Casper et al. (2004) explored the factors that contribute to supervisors' decisions to refer subordinates to work-family programs in the US and report that supervisor awareness of the WLB programs is an important determinant. Swody and Powel (2007) propose conceptual models of the complex, multi-level mechanism behind employee's decisions to participate in their organization's family-friendly programs. The models propose that manager-level variables, such as awareness of, and commitment to, employee family needs and responsiveness to work-family issues, affect employee participation in familyfriendly programs.

Line manager awareness of the various WLB policies in terms of availability, eligibility and specific operational arrangements is an important determinant of their intentions and behaviors towards these policies. In large organizations, line managers can be somewhat removed from the policy driven at a top level and newly appointed line managers will not always be updated about these issues. Good awareness and understanding of WLB options available to line managers for managing their staff is a key determinant in the subsequent choices that these managers make regarding WLB decisions. We, therefore, propose the following:

Proposition 1. Line manager awareness of work-life balance policies and programs will affect their WLB intentions and behaviors.

\subsubsection{Line manager personal WLB policy utilization}

Ajzen (1991) argues that past experiences relating to a particular behavior affect attitudes towards the particular behavior. The extent to which line managers either use or have used work-life balance programs themselves is a factor that will impact their attitudes towards such programs. Line managers' intentions to adopt or put work-life balance options and initiatives in place for staff will be affected by their personal experience with such initiatives. It is expected that line managers who have used WLB programs in the past to address their own personal work-life issues will be more positively disposed to putting such programs in place for their staff. Likewise, line managers who have balanced personal and work demands without the aid of work-life balance interventions may be less likely to see the need for such provisions to be made to their staff. The following is proposed:

Proposition 2. Line manager WLB intentions and behaviors are affected by their personal experience and utilization of such programs.

\subsubsection{Line manager WLB perceived instrumentality}

The TPB argues that a given behavior is predicted by specific attitudes towards that behavior. In terms of our focus on line manager WLB behaviors, line managers attitudes towards the instrumentality and value of WLB programs is an important predictor of their intentions and behaviors. The perceived impact of WLB policies on unit and organizational performance is likely to affect line managers' attitudes towards WLB programs. Casper et al. (2004) found that supervisors who believe that the use of work-family programs will result in positive organizational outcomes make more referrals to such programs. Line management attitudes towards the impact and effect of WLB programs is an important factor in determining what programs are offered (Eversole, Gloeckner, \& Banning, 2007), how employees can avail of these programs (Blair-Loy \& Wharton, 2002), and the benefits such programs accrue at an individual and organizational level (Hyde, Essex, \& Horton, 1993). Less is known about line manager attitudes towards work-life balance programs in general, and the current research does not inform us about the impact of line managers who believe that WLB results in neutral or negative organizational outcomes. Research from the UK indicates that good work-life balance management practices can have a positive impact on competition at the firm level. However, it is likely that line managers who believe that work-life balance policies and practices have positive, or at least neutral, effects on organizational functioning and performance will be more favorably disposed to WLB than line managers who believe these policies and initiatives have negative consequences.

The impact of work-life balance initiatives is a significant consideration for management when deciding if WLB initiatives are to be offered and what initiatives in particular are to be made available to staff. Ultimately, the goals and objectives of the organization in terms of its performance targets cannot be jeopardized by offering programs that might negatively affect business performance. This is a real concern with certain work-life balance initiatives such as part-time working and job sharing where there is an overall reduction in working hours for those participating in these programs. Given that attitudes such as instrumentality and value affect intentions and actual behavior, the following is proposed:

Proposition 3. Line managers' WLB instrumentality (impact) perceptions will affect their WLB intentions and behaviors.

\subsection{Subjective norms - employee demand for WLB}

Changes impacting on the work environment over the past ten to fifteen years such as globalization of competition, changes in the patterns and demands of work, and the fast pace of technological innovations have put extra time demands on employees (Coughlan, 2000; DFEE, 2000; Fisher, 2000; Ryan \& Kossek, 2008). Coupled with these organizational and work design changes are increased female participation rates and an increase in dual-career families (Bates, Bertin, \& Huws, 2002; Eversole et al., 2007; Houston, 1999; Swody \& Powel, 2007), growth in the diversity of family structures (Duxbury \& Higgins, 2001), long commuting journeys (Coughlan, 2000), and changing worker expectations (Greenblatt, 2002; Zemke, Raines, \& Filipczak, 2000). The latter have created demands for time to meet social needs such as time for learning and caring, personal, family and community 
activities. This has forced policy makers and organizations to re-examine the options made available to employees to assist them in achieving a healthy balance between their work and non-work obligations (Eversole et al., 2007; Parris et al., 2008).

The theory of planned behavior informs us that subjective norms affect intentions and behavior and these subjective norms refer to the social pressures to engage or not engage in a given behavior. Employee/direct report demands for accessing and using various WLB policies and programs would be an important factor affecting line manager WLB behavior. In organizations or units where there is more demand from staff for WLB initiatives, it is likely that line managers' intentions to adopt and implement WLB initiatives will be higher compared with organizations are sections where this is less demand from staff. Therefore, we propose the following:

Proposition 4. Direct report/employee demand for work-life balance policies and programs will affect line manager WLB intentions and behaviors.

\subsection{Perceived behavioral control - line manager involvement in WLB policy formation}

The TPB highlights the central role that perceived behavioral control has in affecting intentions as well as actual behaviors. The attitudes towards a particular behavior as set out above reflect the motivation to engage in particular intentions and behaviors. However, an equally important factor in determining behavior is an individual's perceptions about the level of control they have to achieve the behavior in question. Positive attitudes as set out above are insufficient of themselves to achieve certain behaviors since other factors such as power to make decisions, resources, etc. will affect the ability to achieve desired behaviors.

The extent to which line managers are involved in WLB policy formation and have control over WLB issues is likely to affect their WLB intentions and behaviors. Greater line manager participation in the decision-making processes which result in WLB initiatives and policies is likely to affect their perceptions of control over their implementation. McConville and Holden (1999) found that line managers are oftentimes in a difficult position because they have to implement strategies and change initiatives which they have not necessarily been involved in formulating or designing. They go on to report that line managers often suffer stress as a result of trying to implement HR policies determined by senior management without their participation. Maxwell (2005) found that, in organizations that had line manager involvement in WLB policy formation, line managers and employees reported more positive WLB perceptions.

Line managers should have a certain level of involvement in work-life balance program decision-making to avoid the situation where they are managing and implementing policies and changes which they either do not agree with or do not fully understand. Furthermore, line manager involvement in WLB policy formation should result in higher levels of ownership and engagement in WLB management by these line managers. We, therefore, propose the following:

Proposition 5. Line manager involvement in WLB policy formation and design will affect their WLB intentions and behavior.

\subsection{Line manager WLB intentions and WLB behaviors}

As Figs. 1 and 2 propose, intentions reflect an individual's willingness to perform a given behavior. Empirical studies have demonstrated that intentions strongly predict actual behavior (Ajzen, 1991; Armitage \& Conner, 2001; Jimmieson et al., 2008). These intentions, along with perceived behavioral control predict actual behavior. Line manager work-life balance behaviors are of central interest in this paper. Line managers can engage in a variety of different behaviors with regard to WLB. At one level, line managers can be very supportive of employee WLB needs. Line managers who are supportive of WLB tend to advance the WLB policies and practices in the organization and they contribute significantly to the WLB culture. WLB-supportive environments are characterized by line managers who are supportive of employees' personal life concerns (Breaugh \& Frye, 2007; Lapierre et al., 2008; Thomas \& Ganster, 1995; Thompson et al., 2004), the existence of a range and choice of WLB programs (Frye \& Breaugh, 2004; Wang \& Walumbwa, 2007), and a climate where employees are encouraged to utilize WLB policies and programs (Allen, 2001; Carr, Schmidt, Ford, \& DeShon, 2003; Thompson et al., 1999; Warren \& Johnson, 1995; Wise, 2005).

At the other end of the spectrum, line managers can behave in ways that thwart the development and implementation of WLB plans and initiatives. Line managers who are unsupportive of WLB can undermine formal policies and programs designed to aid employees in balancing work and non-work demands (Allen, 2001; Anderson et al., 2002; Thompson, Thomas, \& Maier, 1992; Thompson et al., 1999). Even when formal work-life policies and programs are in place, line managers may subvert them through unevenly applying them and/or not allowing their subordinates to utilize them (Thompson et al., 1999; Anderson et al., 2002). The line manager can, therefore, affect employee WLB outcomes either through deliberate actions or subconscious behaviors.

\subsection{Employee WLB outcomes}

An organization's ability to develop and implement effective WLB policies helps employees achieve a satisfactory WLB. Subjective satisfaction can manifest itself in a variety of ways with some employees not needing to participate in work-life balance policies while others require WLB policies to enable them to satisfactorily manage work and personal life domains. It is the option 
to avail of and engage in suitable WLB practices that is important in determining employee satisfaction with such policies. As discussed above, line manager WLB behaviors will determine subordinate experience and satisfaction with them. While it is not the purpose of this paper to discuss WLB outcomes in detail, we propose that:

Proposition 6. Line manager WLB intentions and behaviors affect the following employee WLB outcomes: employee awareness of WLB policies and programs; employee WLB policy utilization; employee perceptions of managerial support for WLB; and employee WLB satisfaction.

In sum, Fig. 2 suggests that employee WLB outcomes are affected by a number of line manager WLB intentions and behaviors. For example, employee uptake or utilization of a particular WLB program (e.g. term-time) is influenced by the extent to which the line manager encourages and promotes access to and use of this working arrangement. Line managers' intentions and behaviors regarding term-time working are likely to be affected by their awareness of the policy that is in place and how it operates. Their intentions and behaviors will also be affected by their previous experience with using term-time working themselves or operating term-time working for other staff. Line managers who receive more requests and greater demands for term-time working are likely to facilitate employee usage of the WLB program. Further, line managers who have been actively involved and consulted with in devising the term-time policy are likely to be more positively disposed to this particular program and form more positive intentions and behaviors in terms of its use.

\section{Discussion and conclusions}

Devolution of HR decision-making to line management presents both opportunities and challenges. More active line manager involvement in HR related issues enables them to take more responsibility and have more autonomy for how they manage staff. However, the challenges presented are significant and research indicates that inconsistencies can arise in how policies are enacted. As Wise (2005) reports, line manager implementation of one specific work-life balance policy proved inconsistent across two organizations operating under the same corporate policy. This raises serious questions about how line managers enact devolved work-life balance decisions and calls for a greater understanding of how such discrepancies and inconsistencies can be avoided. Employing the theory of planned behavior as a theoretical lens, this paper provides guidance for pinpointing the critical factors that can affect line manager WLB policy and practice behaviors. The model should also assist in informing future empirical research in this area.

\subsection{Implications for research}

A number of commentators point to gaps and deficiencies in the work-life balance research to-date. For example, Poelmans and Sahibzada (2004) criticize work-family research arguing that it has tended to explore the various phenomena at the individual or micro level of analysis. They go on to assert that "only a limited stream of research focuses on the meso-level or, more specifically, the human resource management perspective, where managers in firms make decisions based on the specific internal and external labor market contexts in which they are operate" (p. 413). We support Glynn, Steinberg, and McCartney's (2002) argument for a tripartite view of WLB incorporating the organization, the manager and the employee. Casper, Eby, Bordeaux, Lockwood, and Burnett (2007: 36) draw particular attention to this issue arguing that researchers should use hierarchical liner modeling in multilevel studies to examine effects within units and also cross-level effects. Many studies have explored WLB issues discretely at either an individual employee level or at an organizational level. This paper addresses some of these criticisms by reviewing the role of the line manager as a key meso-level actor in the work-life balance policy and practice nexus. To our knowledge, no study has employed matched datasets to illuminate important line manager influences on employee work-life balance experience at the organizational/policy, line manager, and employee levels. Future research should apply matched line manager and subordinate employee datasets to enable statistical analyses of the impact of varying line manager attitudes towards work-life balance policy on employee level outcomes.

Researchers could adopt the conceptual model presented in Fig. 2 to test each of the propositions and explore which line manager variables in particular affect their WLB behavior and, subsequently, if line manager intentions and behaviors affect important employee work-life balance outcomes. Following Casper et al.'s (2004) statistical analyses approach, each of the predictor and outcome variables presented in Fig. 2 should be measured separately to establish attitudes for particular work-life balance programs. There may be differences for programs which reduce working time (e.g. part-time working and job sharing) and increase administration compared with programs that do not impact employee input (e.g. flexi-time). Likewise, locational based WLB policies may have different effects.

This paper only explored line manager influences on WLB policy and practice. At present, research has not explored the cascading effects of work-life balance policy down through the various management levels to include specifically middle and first line managers. However, in larger organizations, middle managers and line managers may constitute distinct and separate groups with each having potentially different influences on WLB policy and practice. The potentially distinct and varied influences of middle management and first line management in the practice of work-life balance need to be further teased out. Research needs to examine if middle managers, who tend to operate at the meso-level in the firm (Hales, 2006) have particular influences on the enactment of work-life balance policy into practice as distinct from line managers. Hales (2006) argues that the activities and 
functions of these management grades are somewhat different and therefore, we need to understand how each of the stakeholders in the organizational management hierarchy influences the link between work-life balance policy and practice.

We call on researchers to undertake studies that capture multi-level differences in their research design and empirical data collection methods. This might be achieved by ensuring that research designs account for stakeholders who influence the WLB policy-making process as well as line managers who affect WLB policy implementation. Researching employee level WLB outcomes without taking due cognizance of the role of middle and line managers and how they affect employee level outcomes seems somewhat remiss. We argue that, given the critical link line managers play in the WLB policy-practice nexus, researchers should ensure multi-level research designs which capture the influence of line managers. Survey-based research studies which allow for quantitative analyses of the antecedents, mediators and outcomes of WLB policies and practices would provide useful data to facilitate multi-level analyses. Further, comparative multi-site research across a range of different organizations would provide useful insight as to how line managers influence supportive WLB environments and would assist in understanding what determines effective WLB practice from the perspective of line manager behaviors. Comparative research designs would allow us to identify examples of unsatisfactory and satisfactory line manager WLB behavior in different organizations and would facilitate the development of a typology of line manager WLB behavior.

\subsection{Implications for practice}

The case for greater line manager involvement in WLB policy decision-making is clear. McConville and Holden (1999) conclude that middle line managers are increasingly answerable to HR decisions which have largely been made without their input. They go on to highlight the problem of a lack of consistency between strategy and policy implementation as a consequence of poor knowledge of the rationale for such policies. Given insights from the theory of planned behavior, it is critical that line managers are actively involved in designing and developing policies that they will ultimately be accountable for in terms of their implementation and evaluation.

Gilbreath and Benson (2004) report that supervisor behavior affects employee well-being and suggest that organizations seeking to facilitate healthier workplaces should not neglect line manager supervision practices. The finding has significant implications for the work-life balance dimension of employee well-being. The model we propose here suggests that line manager WLB attitude is determined by a range of factors and affects a number of employee work-life balance outcomes. It is important that future research empirically investigates how these factors affect work-life balance. Organizations will then be in a better position to understand how line managers impact the link between WLB policy and practice and, in turn, can undertake measures to address problems in this regard.

The training of line managers in the area would be an important starting point to build awareness of WLB policies and programs, enable consistency in WLB decision-making across line managers as well as employees, and ensure effective implementation of WLB policy at the employee level. Purcell et al.'s (2003) research found that organizations that invested in interventions to improve line management behavior in a longitudinal study reported significantly better employee attitudes and performance post the improvement intervention. This bodes well for WLB attitudes and outcomes where line manager behavior is impeding effectiveness since training could be used to change and improve behavior over time.

Many organizations today herald a broad range of work-life balance policies, arrangements, and initiatives. Purcell et al.'s (2003) study reports that employees tended to be more dissatisfied with existing HR policies which were ineffective rather than being dissatisfied with the absence of policies. This is an important finding which has particular relevance for the current paper. It is important to clearly establish how line managers influence the effectiveness of existing policies and practices rather than feeling the need to introduce new and different policies. While WLB policies and practices are generally viewed as positive for employees, if poorly managed, these arrangements can be problematic. Fairness in terms of employee access to and ability to engage in WLB practices is a very important issue. Some family-friendly programs can result in employees who do not have child or elder care responsibilities feeling aggrieved that their counterparts with care responsibilities are more favorably treated as a result. WLB initiatives which reduce working time such as part-time work and job sharing can create scheduling and rostering challenges for line managers and others who are expected to achieve operational targets and objectives irrespective of particular employee working arrangements. Line managers who are faced with increased administration and complexity in organizing how work is completed because of WLB initiatives may be less favorably disposed to their existence and use.

This paper has argued that line managers are a critical determinant of WLB policy effectiveness. In this regard, it is clear that the role of line managers in determining the success of WLB policy effectiveness is crucial. Research indicates that generation X (those born in the mid-1960s and 1970s) and Y (those born in the late 1970s and 1980s) are unwilling to become hostages to their employers to the extent that their predecessors have been (Bennis \& Thomas, 2002). The role of line managers, therefore, will need to adapt to such changes in employee commitment and expectations (Johnson, 2004). The attitudes and abilities of line managers to make such adjustments will inevitably impact on employee work-life balance experience.

\section{Acknowledgement}

The research is supported by a project grant from the Irish Research Council for the Humanities and Social Sciences which the authors gratefully acknowledge. 


\section{References}

Ajzen, I. (1991). The theory of planned behavior. Organizational Behavior and Human Decision Processes, 50, $179-211$.

Allen, T. D. (2001). Family-supportive work environments: The role of organizational perceptions. Journal of Vocational Behavior, $58(3)$, 414-435.

Anderson, S. E., Coffey, B. S., \& Byerly, R. T. (2002). Formal organizational initiatives and informal workplace practices: Links to work-family conflict and job-related outcomes. Journal of Management, 28, 787-810.

Armitage, C. J., \& Conner, M. (2001). Efficacy of the theory of planned behaviour: A meta-analytic review. British Journal of Social Psychology, 40,471 -499.

Bach, S. (1994). Restructuring the personnel function: The case of the NHS trusts. Human Resource Management Journal, 5(2), 99-115.

Bates, P., Bertin, I. \& Huws, U. (2002). E-work in Ireland, report no. 394. Dublin: The institute for employment studies.

Bedeian, A. G., Burke, B. G., \& Moffet, R. G. (1988). Outcomes of work-family conflict among married male and female professionals. Journal of Management, 14, 475-491.

Bennis, W., \& Thomas, D. (2002). Geeks \& Geezers: How era, values, and defining moments shape leaders. Boston: Harvard Business School Press.

Blair-Loy, M., \& Wharton, A. S. (2002). Employees' use of work-family policies and the workplace social context. Social Forces, $80,813-845$.

Bloom, N., \& Van Reenen, J. (2006). Management practices, work-life balance, and productivity: A review of some recent evidence. Oxford Review of Economic Policy, 22(4), 457-482.

Bloom, N., Kretschmer, T., \& Van Reenen, J. (2006). Work life balance, management practices and productivity. London: Centre for Economic Performance.

Bond, S., \& Wise, S. (2003). Family leave policies and devolution to the line. Personnel Review, 32(1), 58-72.

Boston Consulting Group \& EAPM. (2007). The future of HR in Europe: Key challenges through 2015. London: EAPM.

Brannen, J., \& Lewis, S. (2000). Workplace programs and policies in the United Kingdom. In L. L. Hass, P. Hwang \& G. Russell (Eds.), Organizational change and gender equity: International perspectives on fathers and mothers in the workplace CA, Sage: Thousand Oaks.

Breaugh, J. A., \& Frye, K. (2007). An examination of the antecedents and consequences of the use of family-friendly benefits. Journal of Managerial Issues, XIX, $35-52$.

Carr, J. Z., Schmidit, A. M., Ford, K., \& DeShon, R. P. (2003). Climate perceptions matter: A meta-analytic path analysis relating molar climate, cognitive and affective states and individual level work outcomes. Journal of Applied Psychology, 88(4), 605-619.

Cascio, W. (2000). Costing human resources: The financial impact of behavior in organizations. Boston: Thompson Learning.

Casper, W., Eby, L. T., Bordeaux, C., Lockwood, A., \& Burnett, D. (2007). A review of methods in IO/OB work-family research. Journal of Applied Psychology, $92,28-43$.

Casper, W. J., Fox, K. E., Sitzmann, T. M., \& Londy, A. L. (2004). Supervisor referrals to work-family programs. Journal of Occupational Health Psychology, 9(2), $136-151$.

Colling, T., \& Ferner, A. (1992). The limits of autonomy: Devolution, line managers and industrial relations in privatised companies. Journal of Management Studies, $29(2), 209-227$.

Coughlan, A. (2000). Family-friendly/work-life balance policies. Dublin: IBEC Publishing.

Cunningham, I., \& Hyman, J. (1999). Devolving human resource management responsibilities to the line. Personnel Review, $28(1 \& 2), 9-27$.

Cunningham, I., James, P., \& Dibben, P. (2004). Bridging the gap between rhetoric and reality: Line managers and the protection of job security for ill workers in the modern workplace. British Journal of Management, 15(2), 273-290.

Currie, G., \& Procter, S. (2001). Exploring the relationship between HR and middle managers. Human Resource Management Journal, 11 (3), 53-69.

Darcy, C., \& McCarthy, A. (2007). Work-family conflict: An examination of the differential effects of a dependent child's age on working parents. Journal of European Industrial Training, 31(7), 530-549.

De Cieri, H., Holmes, B., Abbott, J., \& Pettit, T. (2005). Achievements and challenges for work/life balance strategies in Australian organizations. International Journal of Human Resource Management, 16(1), 90-103.

Den Dulk, L. (2001). Work-family arrangements in organizations: A cross-national study in the Netherlands, Italy, the United Kingdom, and Sweden. Amsterdam: Rozenberg Publishers.

DFEE. (2000). Changing patterns in a changing world: A discussion document. London: Department for Education and Employment.

Dopson, S., Risk, A., \& Stewart, R. (1992). The changing role of the middle management in the United Kingdom. International Studies of Management and Organization, 22(1), 45-53.

Duxbury, C., \& Higgins, C. (2001). The 2001 national work-life conflict study. Canada: The healthy communities division, health Canada report.

Eby, L. T., Casper, W. J., Lockwood, A., Bordeaux, C., \& Brinley, A. (2005). Work and family research in IO/OB: Content analysis and review of the literature (1980-2002). Journal of Vocational Behavior, 66, 124-197.

Eversole, B., Gloeckner, G., \& Banning, J. (2007). Understanding differential organizational responses to work/life issues. Journal of European Industrial Training, 31(4), $259-273$.

Fisher, H. (2000). Investing in people, family friendly work arrangements in small and medium sized enterprise. Dublin: The Equality Authority Publication.

Frone, M. R., Russell, M., \& Cooper, M. L. (1992). Antecedents and outcomes of work-family conflict: Testing a model of the work-family interface. Journal of Applied Psychology, 77, 65-78.

Frye, N. K., \& Breaugh, J. A. (2004). Family-friendly policies, supervisor support, work-family conflict, family-work conflict, and satisfaction. A test of a conceptual model. Journal of Business and Psychology, 19, 197-220.

Galinsky, E., Bond, J. T., \& Friedman, D. E. (1996). The role of employers in addressing the needs of employed parents. Journal of Social Issues, 52, 111-136.

Gilbreath, B., \& Benson, P. G. (2004). The contribution of supervisor behavior to employee psychological well-being. Work E Stress, 18 (3), 255-266.

Glynn, C., Steinberg, I., \& McCartney, C. (2002). Work-life balance: The role of the manager. London: Roffey Park Institute.

Grady, G., \& McCarthy, A. (2008). Work-life integration: Experiences of mid-career working mothers. Journal of Managerial Psychology, 23(5), 599-622.

Grady, G., McCarthy, A., Darcy, C., \& Kirrane, M. (2008). Work-life balance policiesE initiatives in Irish organisations: A best practice management guide. Cork: Oak Tress Press. Greenblatt, E. (2002). Work-life balance: Wisdom or whining. Organizational Dynamics, 31(2), 177-193.

Hales, C. (2006). Moving down the line? The shifting boundary between middle and first-line management. Journal of General Management, 32(2), 31-55.

Hall, L., \& Torrington, D. (1998). Letting go or holding on - the devolution of operational personnel activities. Human Resource Management Journal, 8(1), 41 -55.

Harris, R. R., Blair, C. E., \& Grandey, A. A. (2002). Faculty barriers to family-friendly policies: Snapshots from the ivory tower. Paper presented at the 17th Annual SIOP Meeting, Toronto, April.

Hewlett, S. A., \& Luce, C. B. (2006). Extreme jobs: The dangerous allure of the 70-hour workweek. Harvard Business Review, 84(12), 49-59.

Hochschild, A. (1997). The time bind: When work becomes home and home becomes work. New York: Metropolitan Books.

Houston, E. (1999). Work and family issues. In P. Gunnigle (Ed.), The Irish employee recruitment handbook Dublin: Oak Tree Press.

Hurtz, G. M., \& Williams, K. (2009). Attitudinal and motivational antecedents of participation in voluntary employee development activities. Journal of Applied Psychology, 94(3), 635-653.

Hutchinson, S., \& Wood, S. (1995). Personnel and the line: Developing the new relationship. London: IPD Publishing.

Hyde, J. S., Essex, M. J., \& Horton, F. (1993). Fathers and parental leave: Attitudes and experiences. Journal of Family Issues, 14, 616-638.

Jimmieson, N. L., Peach, M., \& White, K. M. (2008). Utilizing the theory of planned behavior to inform change management. Journal of Applied Behavioral Science, 44 (2), 237-262.

Johnson, J. (2004). Flexible working: changing the manager's role. Management Decision, 42(6), $721-737$

Kopelman, R. E., Ptottas, D. J., Thompson, C. A., \& White Jahn, E. (2006). A multilevel examination of work-life practices: Is more always better? Journal of Managerial Issues, XVIII(2), 232-253.

Lambert, S. J. (2000). Added benefits: The link between work-life benefits and organizational citizenship behavior. Academy of Management Journal, $43,801-815$.

Lapierre, L. M., Spector, P. E., Allen, T. D., Poelmans, S., Cooper, C. L., O'Driscoll, M. P., et al. (2008). Family-supportive organization perceptions, multiple dimensions of work-family conflict, and employee satisfaction: A test of model across five samples. Journal of Vocational Behavior, 73, 92-106. 
Legge, K. (1995). HRM: rhetoric, reality and hidden agendas. In J. Storey (Ed.), Human resource management: A critical text (pp. 33-63). London: Routledge.

Maxwell, G. A. (2005). Checks and balances: The role of managers in work-life balance policies and practices. Journal of Retailing and Consumer Studies, 12, $179-189$.

McCarthy, A., \& Cleveland, J. N. (2005). An investigation of work-family conflict in the Irish hotel sector. Paper presented at the European Academy of Management (EURAM) Conference. Munich.

McCarthy, A., \& Garavan, T. (2006). Postfeedback development perceptions: Applying the theory of planned behavior. Human Resource Development Quarterly, 17 (3), 245-269.

McCarthy, A. (2004). Work-life balance in the public sector - The Irish experience. In F. Garibaldo, \& V. Telljohann (Eds.), Globalisation, company strategies and quality of working life in Europe (pp. 431-451). Frankfurt: Peter Lang Publishing Group.

McConville, T., \& Holden, L. (1999). The filling in the sandwich: HRM and middle managers in the health sector. Personnel Review, 28(5\&6), 406-424.

Parasuraman, S., Purohit, Y., Godshaulk, V. M., \& Beutell, N. J. (1996). Work and family variables, entrepreneurial career success and psychological well being. Journal of Vocational Behavior, 48(3), 275-300.

Parris, M. A., Vickers, M. H., \& Wilkes, L. (2008). Caught in the middle: Organizational impediments to middle managers' work-life balance. Employment Responsibilities and Rights Journal, 20, 101-117.

Poelmans, S., \& Sahibzada, K. (2004). A multi-level model for studying the context and impact of work-family policies and culture in organizations. Human Resource Management Review, 14(3), 409-431.

Purcell, J., \& Hutchinson, S. (2007). Front-line managers as agents in the HRM-performance causal chain: Theory, analysis and evidence. Human Resource Management Journal, 17(1), 3-20.

Purcell, J., Kinnie, N., Hutchinson, S., Rayton, B., \& Swart, J. (2003). Understanding the people and performance link: Unlocking the black box. London: CIPD Publishing.

Ryan, A. M., \& Kossek, E. (2008). Work-life policy implementation: Breaking down or creating barriers to inclusiveness. Human Resource Management, 47(2), $295-310$.

Stoker, J. I. (2006). Leading middle management: Consequences of organizational changes for tasks and behaviors of middle managers. Journal of General Management, 32(1), 31-42.

Storey, J. (1994). How new style management is taking a hold. Personnel Management, 25(1), 32-35.

Swody, C., \& Powel, G. N. (2007). Determinants of employee participation in organizations' family-friendly programs: A multi-level approach. Journal of Business Psychology, 22, 111-122.

Thomas, L. T., \& Ganster, D. C. (1995). Impact of family-supportive work variables on work-family conflict and strain: A control perspective. Journal of Applied Psychology, 80(1), 6-15.

Thompson, C. A., Beauvais, L. A., \& Lyness, K. S. (1999). When work-family benefits are not enough: The influence of work-family culture on benefit utilization, organizational attachment and work-family conflict. Journal of Vocational Behavior, 54(3), 392-415.

Thompson, C. A., Jahn, E. W., Kopelman, R. E., \& Prottas, D. J. (2004, 12). Perceived organizational family support: A longitudinal and multilevel analysis. Journal of Managerial Issues, 16(4), 545-565.

Thompson, C. A., Thomas, C. C., \& Maier, M. (1992). Work-family conflict and the bottom line: Reassessing corporate policies and initiatives. In U. Sekaran \& F.T. Leong (Eds.), Woman-power: Managing in times of demographic turbulence (pp. 59-84). Newbury Park, CA: Sage.

Veiga, J. F., Baldridge, D. C., \& Eddleston, K. A. (2004). Toward understanding employee reluctance to participation in family-friendly programs. Human Resource Management Review, 14, 337-351.

Wang, P., \& Walumbwa, F. (2007). Family-friendly programs, organizational commitment, and work withdrawal: The moderating role of transformational leadership. Personnel Psychology, 60, 397-427.

Warren, J. A., \& Johnson, P. J. (1995). The impact of workplace support on work-family role strain. Family Relations, 44, 163-169.

Whittaker, S., \& Marchington, M. (2003). Devolving HR responsibility to the line: Threat, opportunity or partnership? Employee Relations, 25(3), 228-261.

Wise, S. (2005). The right to time off for dependants. Employee Relations, 27(2), 126-140.

Worrall, L., Jones, B., \& Cooper, C. L. (2003 July). Redefining organizational wellbeing: Just what is a work/life balance in today's climate. UK: SCOS XXI Cambridge.

Zemke, R., Raines, C., \& Filipczak, B. (2000). Generations at work: Managing the clash of veterans, boomers, xers, and nexters in your workplace. Training $\mathcal{E}$ Development, 54(1), 60-71.

Dr Alma McCarthy is an MBA Program Director and Lecturer in Management at the National University of Ireland, Galway. Her research interests include performance management, employee training and development, work-life balance, and multi-rater $\left(360^{\circ}\right)$ feedback systems. She has published books, book chapters, peer-reviewed articles in journals such as Personnel Review, Advances in Developing Human Resources, Journal of Managerial Psychology, Journal of European Industrial Training, the International Journal of Manpower Studies, and the Journal of Vocational Educational Training as well as presented papers at reputable national and international conferences. She is on the Editorial Board of the Journal of Managerial Psychology and the Journal of European Industrial Training and currently serves on the national council of the Irish Academy of Management (IAM) as Vice-Chair.

Dr Colette Darcy is a Lecturer in Human Resource Management at the National College of Ireland. Her research interests include organizational justice, work-life balance and the changing nature of employment and she has presented her work at national and international conferences including the Irish Academy of Management, the International HRM Conference and the European Academy of Management. Prior to returning to academia, Colette worked for a number of years in management consultancy specializing in reward strategies and change management.

Geraldine Grady is a researcher at the Centre for Innovation \& Structural Change (CISC) at the National University of Ireland, Galway. She works as a consultant to many private and public sector organizations and lectures at the Galway-Mayo Institute of Technology (GMIT) in the areas of Human Resource Management, Organizational Behavior, and Human Resource Development. Her research interest is work-life balance and she has presented her work at national and international conferences. 